\title{
Constructing Ethical Corporate Social Responsibility and Citizenship in Auto-Industry Operations: Why Consumers Deserve the Best
}

\author{
Robert Pech (Corresponding Author) \\ Khalifa University of Science and Technology, PO Box 127788, Abu Dhabi, United \\ Arab Emirates
}

Tel: 971-2-401-8000 ext. $8521 \quad$ E-mail: Robert.pech@ku.ac.ae

Received: Nov. 7, 2018

Accepted: Nov. 28, 2018 Published: December 28, 2018

doi:10.5296/bms.v9i2.14140

URL: https://doi.org/10.5296/bms.v9i2.14140

\begin{abstract}
This article focuses on the need to accompany contemporary innovation and manufacturing with ethical management, operations and production. The investigation emphasizes operations in the automotive industry through the spectrum of Corporate Social Responsibility and Corporate Citizenship. Corporate Citizenship is seen in a new light. In recent years, the profit versus consumer-safety problem has led to injuries and deaths of hundreds of consumers in the automobile industry, some of which are evidently the result of human negligence and abnegation of responsibility often in efforts to reduce overheads and maximize profits. This erosion of corporate social responsibility may not only lead to consumer death, injury or disillusionment but also to company ruination because it sets in motion a downward spiral in consumer confidence, followed by investigations, law-suits, and fines resulting in corporate disarray. The research draws a distinction between CSR and CC to help analyze the auto-industry.
\end{abstract}

Keywords: Ethical operations management, Profit versus consumer-safety problem, Public perception, Corporate social responsibility, Corporate citizenship, Corporate self-defeat 


\section{Introduction and Background}

This article focuses on the need to accompany contemporary innovation and manufacturing with ethical management, operations and production. By "ethics" the author means "the principles, norms, and standards of conduct governing an individual or group." (Trevino and Nelson, 2011, p. 17). Although the issue is manifest in many industries we will highlight the auto-industry as one notable example. Innovations, as normally found in a plethora of consumer products, usually comprise high technology as the result of long research processes and large investment. Innovative products enter the consumer market at a prodigious rate to meet or create demand; therefore, the need for reduced-cost production often means increased risk to achieve first-to market advantage in ever more competitive environments. The risks are not only financial and can involve the welfare and safety of consumers who often assume that products have been satisfactorily tested over time to assure safety and quality. Regardless of products' convenience, better service or cheaper cost, safety in their usage is not guaranteed.

Customers should not tolerate ethical compromise when it occurs. There are disconcerting discrepancies between manufacturers and consumers in some industries from time to time which indicate that there are indeed troubling ethical gaps. Manufacturers may ignore them to achieve commercial success or continue commercial success without interruption. Companies that commit primarily to their shareholders have been known to do so at the expense of their customers and the general good. Examples of imperfect innovative technology and expediency in recent times include the volatility of Takata airbags which led to death and injury and then the recall of millions of vehicles worldwide; the fatal ignition problems experienced with some General Motors saloon models, leading to 124 deaths; and the fraudulent actions by Volkswagen with regard to their emission controls. The ethics relating to consumer safety in each case can be seriously called into question, and a failure to comply with ethical standards has impacted the reputation of each brand.

Therefore, it is fair to ask to what extent high-tech industries and businesses pay attention to ethical operations in safeguarding consumer and other stakeholder protection. There is no FDA equivalent for companies' products and they are market leaders - and so there was no regulatory inspection, and no effective consumer protection. Design faults were either overlooked or inadvertently missed by these companies' quality control procedures, which undermines their very purpose. To be fair, there are times when visual inspection cannot detect defects and companies must place trust in their suppliers. (http://www.strategy-business.com/blog/The-True-Lesson-of-an-Airbag-Disaster?gko=bcbc1). They tacitly assume that the responsibility for safety lies with the suppliers and that this is understood and agreed upon by both parties. (Ibid. p.3).

In examining this matter, it is necessary to distinguish between corporate social responsibility (CSR) and corporate citizenship (CC). These two concepts are closely allied and discussed in the literature. However the literature so far does not define their differences with clarity. A case will to be made that CSR refers to a company extending a share of its profits outwards to 
the society that it serves, and CC on the other hand is the company looking inwards to its own culture and the needs of its production stakeholders, such as its employees. Where all of these are appropriately aligned, a company is less likely to deviate from its corporate objectives by avoiding the descent into making defective products.

General Motors' ignition defects led to 124 deaths. The company's newly appointed CEO at the time of the ignition-switch debacle, Mary Barra, was notified in January 2014 that there was a serious problem with the switch in some models. At first, 2.6 million vehicles had to be recalled. Upon investigation, the faulty ignition was responsible for 124 deaths and more than 500 injuries. As an outcome of the report compiled by former US attorney Anton Valukas, a $\$ 400$ million victim-compensation fund had to be established. His 325 page report came to the conclusion that people inside the company had been aware of the faulty switch since 2001 . For 13 years none of them had the initiative nor the audacity to confront the problem. Mary Barra had to contend with investigations into her company by the US Department of Justice, the Securities and Exchange Commission and settle an accumulation of private law-suits. But as 2014 continued, the company recalled almost 30 million vehicles world-wide. These did not involve only vehicles with ignition problems but also other issues of generally poor engineering. The consequences of this neglect were not only serious for the consumer but also the producer.

Similarly, there was a vehicle recall of unprecedented proportions by several auto makers due to the Takata airbag they carried. Their airbags were found to be defective because a volatile inflator and propellant gases could shoot metal fragments towards the driver and passengers. A New York Times report in September 2014 claimed that a total of 139 injuries could be attributed to this fault. More than 34 million vehicles had to be recalled.

In many countries, there is no external, independent overview of product safety when an innovative product or component product is launched. Of course, accidents can and do occur periodically, and by their very nature cannot be avoided - that is an accepted fact. Human error and circumstances beyond human control do happen. But when they occur regularly in a product or process, they are no longer accidents. This is particularly so when employees within companies sabotage their own best efforts by failing to report problems, or worse still, when negligent management ignores their reports of safety breaches. Takata and General Motors appear to be cases in point for lack of responsibility in this regard. The problem is difficult to resolve. The interests of consumers and shareholders appear to be diametrically opposed. Both parties are becoming equally vociferous.

\section{Literature and Theory}

Chui, (1999); Kogan, Papanikolaou and Stoffman, (January 2013); Hall and Rosson (2006); and Papanikolaou again in 2014 raised the issue of winners and losers in this scenario. Hall and Rosson wrote that "Innovative activities thus create both winners and losers, making it a major focus of both management and policy makers.” (64: p.231). Furthermore, they argued that "a key challenge facing new Internet companies, incumbent firms and other stakeholders 
is to understand the interconnected relationships between technological innovation and sociopolitical legitimacy.” (Ibid. p.232.) This is further supported by Baron (2012). Meel and Saat took a pragmatic view opining that "the problem of product safety is inseparably connected with business effectiveness: how much can we spend on product safety without making or production unprofitable?” (2002, p.21). And to that they added the very relevant point of the length of time that companies and consumers are prepared to wait before all potential dangers have been addressed. (Ibid. p.23). To Meel and Saat, a product's ethical life-cycle consists of the stage of producer/consumer ignorance, the stage of an ethical dilemma when problems are caused by the product, and the stage of legal regulation when governments intervene to ensure safety. (Ibid. p.23). But it is their "malevolent disregard" epithet that is particularly relevant to this investigation as will become clear. (Ibid. p.25).

Fabian and Fabricant (2014); Bryden and Gezelius (2017); and Fondrona (2013) supported the view that there was an interconnectivity, "A positive, comprehensive view of ethics will make us realize that ethics and innovation are closely related: that innovation - like any other human activity - is deeply rooted in ethics, and that ethics inspires and encourages innovation.” (p.23). She not only believes that ethics in industry is an end in itself but also a roadmap towards achieving it, "Ethics not only reflects on what it means to become better human beings, it also gives us pointers on how to achieve it." (Ibid. p.24). Porter and Kramer believed that producer and consumer should reciprocate in a form of "shared value" which they described as "societal needs, not just conventional economic needs, define markets." (2011).

Mintzberg, Simons and Basu concluded that corporations have become too focused on the creation of short-term shareholder wealth and are now too greedy at the expense of the long-term interest of the corporation and its shareholders: "Greed has been raised to some sort of higher calling; corporations have been urged to ignore broader social responsibilities in favor of narrow shareholder value; chief executives have been regarded as if they alone create economic performance ... A syndrome of selfishness has taken hold of our corporations and our societies, as well as our minds” (Mintzberg et al., 2002, p. 67). Consumption, and self-serving behavior have become not only acceptable in society, but may be seen as a desirable trait in some segments. Cooke (1997) clearly noted that "greed", or the quest to obtain superior returns, was one of the motivating forces for entrepreneurs to commit themselves to a start-up. According to Cooke public corporations have a duty to act on the behalf of their owners and if they do not they are not fulfilling a prime function.

Cooke made legitimate point, echoing Edward Freeman who claimed that corporations only had a social responsibility to shareholders, (1970). However, Mintzberg has continued to wage a campaign against wayward producers for over 15 years, calling into question the manufacturers' ethics and lack of concern for the consumer public by their display of base human emotions such as apathy, and abnegation of responsibility. Meel and Saat pointed out in 2002 that Ford may have produced the Pinto and Manville produced asbestos, but that both manufacturers did so within legal perimeters. So in 2003, Simon Caulkin criticized 
Mintzberg of having developed "a pretty outspoken diagnosis," and observing that the way Mintzberg perceived his world was "scary." But more acerbic judgments were yet to come from Mintzberg in his blog dated 31 March 2016, in which he was particularly caustic in comparing the "Statement on Corporate Responsibility" issued by the Business Roundtable in 1981 and then its 1997 issue on "Shareholder Value." The former acknowledged the need for balance between the interests of the consumer and producer; the latter focused exclusively on the interests of the producers.

In relation to this conundrum, let us now turn to CSR and CC. CSR and CC are often used inter-changeably. Andrews (1971) defined the principal concerns of CSR that have attained general consensus among theorists: "The integration of ethical, moral and stakeholder considerations into strategy decisions is the essence of today's corporate social responsibility.” (p. 100). CSR is an important feature of contemporary corporate life. It has been described "in terms of the social and environmental impact of systemic organizational activity,” (Maclagan, 1999 p.43). And Gond (2006) defined CSR simply as "the interface between business and society.” (Cited in Hemingway, 2013). Both CSR and CC have organizational values at their base. One definition of CC is, "the commitment of business to contribute to sustainable economic development, working with employees, their families, the local community and society at large to improve their quality of life.” (WBCSD, 2000, p.10). This means that corporations target one or more responsibilities to provide for, or to consider the needs of, civil communities within society which local and national government may not think of as having priority but which nonetheless deserve financial and other group support through a program of assistance. Hemingway goes on to explain that capitalism's over-riding preoccupation, the maximization of wealth, is considered by some to have gone to excess, with the gap between the rich and the poor continuing to divide society. Under CC, industry and society are often seen as sharing a symbiotic relationship. But many companies consider that the range of responsibilities and sponsorships to which they commit themselves should fall into the specific range of interests of their stakeholders - not wider society as a whole. These limitations are understandable within the huge range of financial needs expressed by a wide variety of interest and pressure groups within society. No one company can cater to all demands. Therefore, many of them tailor their support to their employees, for example in the form of competitive salaries, promotion possibilities and insurance schemes. However, employees should understand that under CC, giving the best years of their life to a corporation in exchange for remuneration and benefits, should also mean taking their share of individual ethical responsibility.

CC is a relatively new element in the lexicon of business; so new, it is not even defined in the Oxford Dictionary of Business and Management, $4^{\text {th }}$ edition published in 2006. Yet it is not entirely original - rather a tangential aspect of CSR. Carmen Valor believes that companies should be in tune with society and that the "individual good citizen" is not difficult to identify. By inference, she believes that therefore "citizens" should behave that way. (2005). But does being good need to be enforced or can good behavior be voluntary? Boyton is cited in Stangis and Valvoda Smith as asserting that "at its heart, corporate citizenship is change management. 
It is about envisioning a different and better future for business and society. Change management requires the skills of both leaders and managers [...] Leaders call for leadership from every seat. They make it clear that everyone should step up and find their spots as a leader, regardless of rank, title, or position. (2017, pp. xiv-xv). Stangis and Valvoda Smith themselves do not distinguish between CSR or CC, "Don't worry if your company calls it something different," (Ibid. P. xxxvi). They believe that "corporate citizenship is [vital] to every aspect of the business. Managing the environmental and social impacts of your company and using the assets of business to create value both for the firm and for the world at large is critically important to the future of our environment, society, and economy. It is the way that leading companies are creating competitive advantage today.” (Ibid. P. xxxvii). In fact, their view is that CC is best characterized as a program:

"Corporations integrating these programs into their business strategy are 2.2 times more likely to gain access to new markets, and 2.3 times more likely to achieve employee retention. (p. xxxii). The more logically connected your corporate citizenship priorities are to your company's strategy, the more authentic and credible your program will be perceived to be by stakeholders of all types - customers, employees, shareholders, and community members - and the more value both your company and society will derive from the investment.” (p. xxxiii).

Carmen Valor observed in 2005 that CC needed a "reconceptualization" and it is clear that this reconceptualization should begin with a refined definition which separates it from CSR and the confusion that the interchangeability of its use can cause. Achieving that new definition then opens a new window to the problems in the auto-industry with possible solutions because it provides a fresh perspective.

\section{The Role of Corporate Citizenship: Towards a More Refined Understanding}

Crane and Matten define corporate citizenship as "the corporate role in governing citizenship rights for individuals.” (2016, p.73). They refer to social, civil and political rights with regard to the citizen's protection and the implementation of those rights. (Pp. 69-71). The implication is that a corporation must in various ways be more accountable for the consequences of its actions than it would ordinarily be under the traditional concept of CSR.

Yet under the circumstances described in this research, this definition and its implications do not go far enough. Under the definitions above, the onus of ethical responsibility rests mainly, if not solely, on the shoulders of management. But we know from post-modern organizational practice that management cannot always take sole responsibility for everything that occurs in a company. The responsibility has to be shared between management and all its stakeholders, especially its employees because they are the ones who actually implement strategy and produce the products. Hatch and Cunliffe (2006) offer insights including the observation that "long-linked" technologies distance management from non-management because manufacturing companies' transformation processes are linear: there are inputs in one end and products out the other. Within such a routine operation from day to day, new technologies 
such as in the automobile industry, are not always understood by operators, and with the degree of automation and robotics prevalent today, this is not always necessary for smooth continuity of production. Therefore, unexpected interruptions such as defects are not dealt with in technologically precise ways and may even be underplayed - if not ignored altogether, (pp. 149-154). Hatch and Cunliffe also observe that employees can grow so weary through repetitive action that they can resist managerial control through sabotage or complete non-responsiveness, perhaps because they will not assume responsibility. And largely due to the operations of artificial intelligence, the human dimension is diminished: "technology undermines hierarchy”, (Ibid. p. 142). Therefore the author points to a flattening or democratization process at work. Taking responsibility is not what employees are paid for; they are paid for production. Principally, under postmodernist work practices, the model has evolved: human relationships in manufacturing used to be in the form of a hierarchy but now it tends more towards self-determination. (Ibid. p. 56). And operation-level employees can determine to ignore problems.

Harmonizing the interests of the company and society is difficult. The problem canvassed thus far by the commentators above relate to a number of human elements. Humans are prone to fallibility. Accidents can happen, but some people extend fallibility to a willful extreme. At that end it can result in such faults as the dereliction of duty. In analyzing this situation commentators have pointed to the less admirable human traits of selfishness and greed, with the implication that if these darker emotions could be curbed it would lead to fewer issues related to the shareholder versus consumer nexus. But can they be curbed? That leads to the question of whether "normal" human fallibility, as in the case of unintentional faulty design or unanticipated accidents, can be tolerated as inevitable, as expressed by "It happens.” But is it also inevitable that human fallibility in the form of negligence should be tolerated? Particularly if it becomes, technically speaking, criminal negligence. It should not. Attempts should be made that this extreme in the spectrum of human fallibilities be better controlled so as to prevent the deaths of others. Unless action is taken, the problem will continue as an "uncontrolled variable" which could continue to cause more havoc, (Ackoff, 1978), meaning that more consumers will inevitably suffer from defective goods. Could a new concept, and hence practice, of corporate citizenship help alleviate this dilemma? A distinction can be made between CSR and CC if CSR is taken to be the business to society nexus focused on outside stakeholders, and CC is taken to be the business nexus with its internal stakeholders. It is the difference between the connection between, for example, the business and its shareholders and the business and its employees. Employees could then be regarded as "citizens" within a corporation, hence "corporate citizens," who are encouraged and supported to implement company strategy with a deliberate focus on edifying their company by sharing the responsibility for its success - and failures. This edifies Boyton, mentioned above, when he called for leadership: "regardless of rank, title, or position.” (2017, pp. xiv-xv). It is also relevant to a company considering the balance between shareholder and stakeholder interests. 
Table 1. Differences between CSR and CC

\begin{tabular}{|c|c|}
\hline $\begin{array}{c}\text { Corporate Social Responsibility (CSR) } \\
\text { Company focuses outwards to society }\end{array}$ & \multicolumn{2}{|c|}{ Corporate Citizenship (CC) } \\
Company focuses inwards to its own culture
\end{tabular}

Table 1 differentiates between the prime concerns of CSR and CC. That is particularly relevant to the thesis of this investigation. Who was responsible in the cases of GM, VW and Takata? To overcome this problem there needs to be a new way of looking at corporate citizenship. CC should be removed from the definition that concentrates on the relationship between industry and society. Lack of internal alignment between strategy as defined by management and practice as implemented by non-management obviously has the potential to be detrimental to a company. Definitions of CSR - and by lexical connection to CC - thus far have proffered the need for partnerships, like the company and society. But one important partnership has not been recognized: the one between management and non-management. Citizenship in corporates should include the reciprocal relationship between management and non-management to achieve goals whereby everyone is equally responsible. If the elusive and confusing term "corporate citizenship" could be extended, and modified to refer to a democratization process within a company comprising rights as well as obligations, the automobile industry issues discussed in this paper can be seen in a new light. It necessitates "citizens" in a corporate who must contribute more in the auto-industry than they did in the cases under consideration. Under a post-modernist interpretation of product design and manufacture the internal linkages between management and non-management have to be reinforced to enhance mutual trust and respect so that the identification of product defects is seen as beneficial to all parties in companies. Where there are divides there can be little collaboration to avoid the spirals of defectiveness that have plagued the auto-industry. That then focuses particularly on the resulting divide between whether the shareholder or consumer should have priority. Without greater emphasis on ethics and leadership, management and non-management alike will suffer confusion and conflicting demands. 
4. Corporate Social Responsibility and Corporate Citizenship: Compromises and Failures

The examples that follow focus mainly on defective products and how the inadequacy of CC as defined above was largely responsible. These defects were not random. They were the result of management and non-management in each case demonstrating a disregard for human life - their own consumers' lives. In short, those who died were consumers. Each example to come identifies actions which resulted in people suffering injury or dying. As well as that, in each case there is a demonstrable discrepancy between what companies said and what they did. This investigation then, delineates differences between CSR and CC by drawing attention to internal corporate alignments leading to dishonesty, the lack of integrity, and the inclination that companies increasingly appear to have for willfully ignoring their responsibilities. These go beyond shareholder interests alone. Consumers must be accorded equal rights. Kilkullen and Kooistra believe that the ethical, moral and stakeholder dimensions which inform corporate strategy is the "essence" of industrial social responsibility, (1999). But when seen as an internal form of corporate citizenship the issue intensifies. Why did employees on the shop-floor not attempt to influence managerial attention and strategy more diligently when the process resulted in defects? Under a system of reciprocal rights and obligations, both management and non-management should have equally shared the responsibility of correcting the problems because they were in it together. This was not just about assuming or relinquishing responsibility. When corporate citizens do not understand that both parties share responsibility, tragedy can occur.

\subsection{Problem Statement}

Freeman contended that industry's first responsibility was to its shareholder interests. His stakeholder concept included planning, systems theory and operations and general organizational theory all of which comprised strategic stakeholder management, (1984). But he did not mean that by contrast, its consumers had an interest in being injured or dying. Product defects must be rectified - immediately. Not ignored for years. Peter Drucker first stated: "The proper social responsibility of business [...] is to turn a social problem into economic opportunity and economic benefit, into productive capacity, into human competence, into well-paid job, and into wealth.” (1984, p.62). Companies must bear responsibility for the quality of their products, services and workplaces in which all of their stakeholders can assert rights, receive fair treatment unconditionally, as well as claim an equitable slice of the corporate pie. So the problem statement focuses on: the dilemma that is created in the multiple tensions that arise between CSR and CC, as well as shareholder and consumer interests, and what can be done to prevent companies from exacerbating defective products and services that lead to injury and death by one or both parties abnegating responsibility.

\subsection{Jeopardizing Lives Through a Lack of True Citizenship in the Automobile Industry}

Moral leadership in corporations cannot succeed unless the interests of internal and external 
stakeholders can be harmonized. There have been disconcerting discrepancies between what company CSR statements profess and companies' actual behavior. This makes “citizenship” a fragile concept. Corporations do not regularly enact the reciprocity of internal ethical responsibilities between management and non-management. Contemporary corporate behavior has impacted on the design and quality of its products. Inevitably, this has led to situations in which human life has been endangered. People have not only died by accident. In otherwise reputable companies, management and employees alike have been fearful, apathetic, negligent, or financially over-conscious. There have been instances in which the abnegation of responsibility has compromised product safety, services and processes. The sanctity of human life is a value in all cultures and religions, and it is at the core of many derivative values. Human safety should be one of those. But it seems to be have become reduced to a matter of corporate opinion, rather than a value, as to whether human safety and life are still a "responsibility” under the umbrella of CSR. Brusoni and Vaccaro were strongly critical: "Strategies mostly focused on social accounting only, a quite typical approach in current times, are unsuccessful because they fail to boost the process necessary to re-introduce and operationalize in day-to-day life pro-social values and objectives,"(2016, p.16). This discrepancy is problematic. But if CC were re-interpreted to provide employees with self-determination to intervene in a problem rather than to ignore it, the situation might be more easily resolved.

\subsection{A Deteriorating Situation in the Auto-Industry}

Table 2. The Low and High Ends of Ethical Corporate Citizenship

low $\rightleftharpoons$ Corporate Citizenship $\rightleftharpoons$ high

\begin{tabular}{|c|c|c|c|c|}
\hline created & Problem & & & solved \\
\hline low & Human ethics ans & respect for law & & high \\
\hline $\begin{array}{l}\text { Unacceptable } \\
\text { ethics and risks }\end{array}$ & $\begin{array}{l}\text { Unreasonable } \\
\text { ethics and risks }\end{array}$ & $\begin{array}{c}\text { Normal } \\
\text { Human } \\
\text { fallibilities } \\
\end{array}$ & $\begin{array}{c}\begin{array}{c}\text { Reasonable } \\
\text { ethics and } \\
\text { risks }\end{array} \\
\end{array}$ & $\begin{array}{c}\text { Acceptable } \\
\text { ethics and } \\
\text { risks } \\
\end{array}$ \\
\hline $\begin{array}{l}\text { Lack of appropriate } \\
\bullet \quad \text { Testing } \\
\bullet \quad \text { Supervision } \\
\text { Ptand-down } \\
\text { Neriods } \\
\text { Neglect } \\
\text { Dereliction of duty, } \\
\text { responsibility and } \\
\text { safety } \\
\text { Greed }\end{array}$ & $\begin{array}{l}\text { Lack of appropriate } \\
\bullet \text { Resources } \\
\bullet \text { Expertise } \\
\bullet \text { Time } \\
\bullet \text { Experience } \\
\text { - Finance } \\
\text { Wrong "formula" } \\
\text { for success } \\
\text { Partial "formula" } \\
\text { for success } \\
\text { Inferior material }\end{array}$ & $\begin{array}{l}\text { Accident } \\
\text { Carelessness } \\
\text { Flawed design } \\
\text { Untested } \\
\text { assumption } \\
\text { Unanticipated } \\
\text { danger } \\
\text { Chance and } \\
\text { hope }\end{array}$ & $\begin{array}{l}\text { Industrial } \\
\text { competition } \\
\text { Market } \\
\text { forces } \\
\text { Prime mover } \\
\text { advantage } \\
\text { Work } \\
\text { pressure } \\
\text { Deadlines }\end{array}$ & 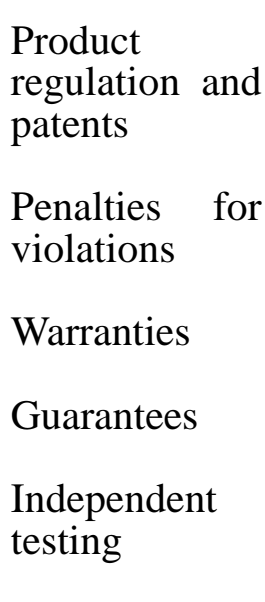 \\
\hline
\end{tabular}




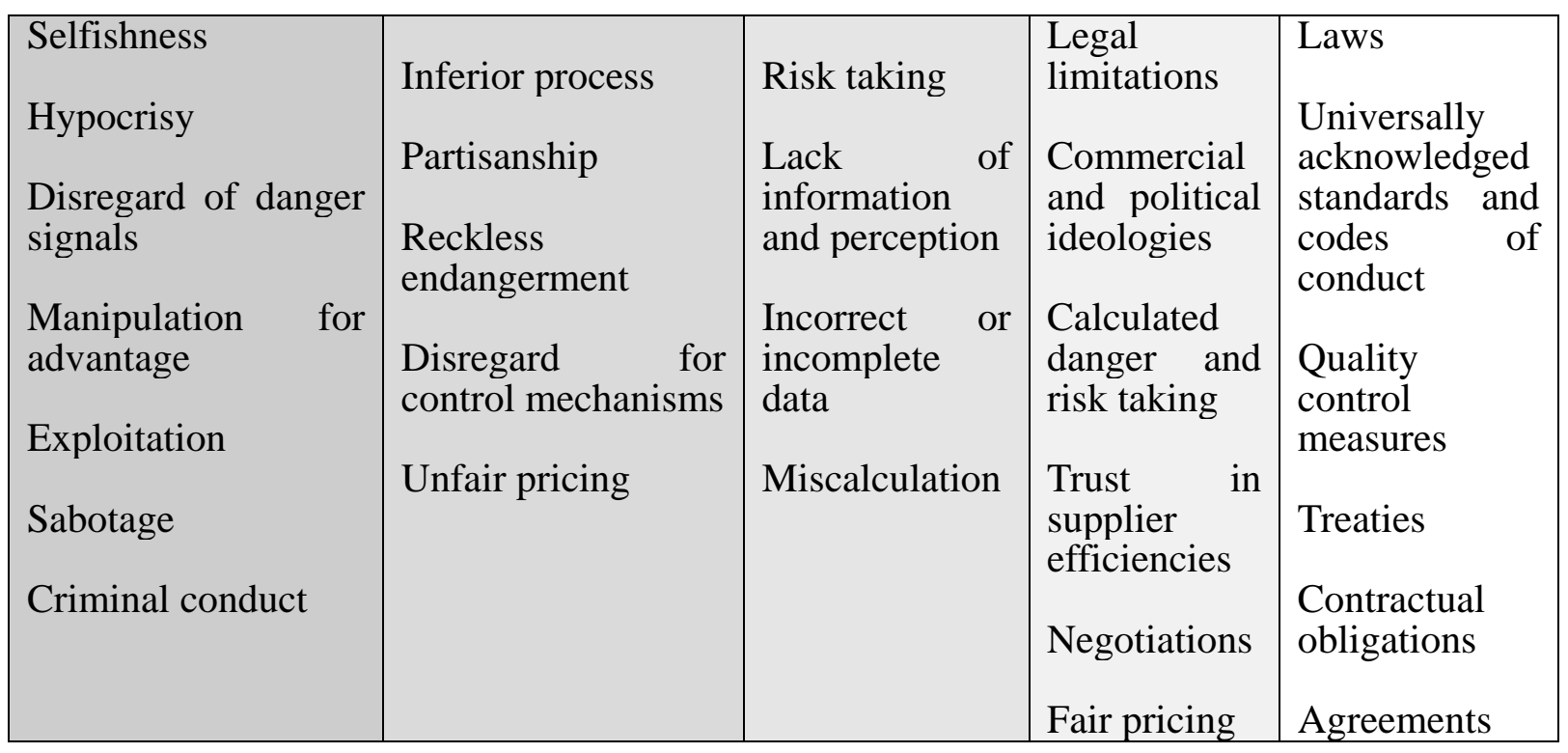

Table 1 shows the range of human fallibility from the acceptable to the unacceptable with variable acceptability in the middle. Where respect for ethics and law is high, producers solve problems; where it is low, producers create problems. Serious problems cause consumers to be endangered. What is not self-evident is that those at the extreme left end of the chart, in the "Unacceptable ethics and risk" category, are also endangered. They cause problems for themselves in which the outcomes may be industrial disruption at best and law-suits relating to manslaughter at worst. A more robust form of CC within a corporation can alleviate this.

But firstly, some examples will serve to illustrate a deteriorating situation. Auto makers especially seem at the forefront of industrial negligence in recent years. General Motors appointed Mary Barra as the new CEO in January 2014. Her first crisis was that the company was reportedly producing small to medium cars with faulty ignition switches, particularly in the Chevrolet Cobalt, which led to the recall of 29 million vehicles worldwide, (http://www.industryweek.com/corporate). It has been established that 124 deaths and 54 injury accidents could be attributed to the malfunction over a period of 13 years. (http://www.industryweek.com/quality). The internal investigator, Michael Valukas believed that the ignition problem was detected as early as 2001 and went on to cause multiple casualties by switching off the electrical systems whilst the car was in motion. This led to problems with lights, airbags and other failures. Barra took responsibility: "The Cobalt saga was riddled with failure [...] we misdiagnosed the problem from the very beginning [...] we have to own this problem.” (http://industryweek.com/companies). By June 2014, 74 law suits had been filed quickly followed by congressional and federal investigations. Their focus was on the delay and inaction over a period well exceeding a decade and this led Barra to set up a new "product-integrity" team so that any other technical problems which might develop in due course would receive immediate attention. Commented Barra, "This new way of developing vehicles will provide the highest levels of safety, quality and customer service and ensure that a situation like the ignition-switch recall doesn't happen again." (http://www.industryweek.com/transportation). However, that is an industry perspective and 
not a statement that conveys regret over human loss. Fortune reported in 2016 that there were "399 viable claims, of which 124 were deaths and 17 were people who suffered injuries such as quadriplegia, paraplegia, double amputations, permanent brain damage and serious burns.”. To compensate their victims, General Motors anticipated having to pay \$625 million in damages. (http://fortune.com/2015/08/24/Feinberg). As a result of an internal investigation 15 employees were dismissed. But the company concluded that there was no evidence of management neglect. The most severe legal penalty that GM paid was a $\$ 900$ million fine for wire fraud and not disclosing information to regulators about the defective component. (http://fortune.com/2015/09/18).

Takata Airbags' situation was also cause for concern. This was not in terms of the number of fatalities but because the company turned a deaf ear and blind eye despite even their own engineers warning their management. Failure to redress their exploding airbags with lethal impact resulted in at least 17 deaths and more than 100 injuries between 2002 and 2015, 11 of them in the USA. (https://www.cnbc.com). According to the same source, the likely cost of the recall might add up to $\$ 10$ billion, a sum which has not yet finally been settled upon. The issue was that Takata replaced an older but reliable propellant with a cheap but volatile one. Tetrazole had been replaced by ammonium nitrate which was ten times cheaper, but under humid conditions, it could explode with sufficient force to launch metal shrapnel through a car cabin. By 2016, consumer reports claimed that 100 million vehicles with faulty inflators would need to be replaced. Takata at that point calculated that it would complete the repairs by 2019. (http://www.consumerreports.org/cro/news ). By October 2016, nine deaths due to this fault took place in Acura and Honda models in the USA but there were still 300,000 vehicles that needed to replace their inflators in the country, and when auto owners failed to act immediately, it caused concern. (Ibid. p.2). Honda was the most affected company with about 20 million recalls by August 2015. (http://www.strategy-business.com/blog/). Honda claimed that it did not have the necessary inspection instruments to detect the problems and admitted that it had ignored reports of inflating airbags scattering shards of metal injuring drivers and passengers alike. However, the problem also afflicted Audi, GM, Jaguar, Mitsubishi, Toyota and Volkswagen. Bloomberg Businessweek reported, that even Takata's own engineers, such as Mark Lillie, had for years warned company management of the danger because the new propellant was too unstable. (Orlove, February 2016). But the company was expedient. Commented Lillie, "They spent hundreds of millions of dollars on the facility. Takata was working hard to catch up and grab market share by being technologically sophisticated. We were moving so fast. It was terrifying, but exciting." (Ibid. p.3). In 2006 there was an explosion in the factory, and as late as 2011 an email circulated criticizing employees for attempting to fix defective inflator components when they should have been discarded and replaced. (Ibid. p.5). Even in 2008, the management at Takata refused to change ammonium nitrate to a safer chemical. And yet, Takata's CSR statement claims that "Takata Corporation engages in the manufacture and sale of automotive safety systems and products for automakers worldwide.” (Emphasis by author.) (https://www.csrhub.com/CSR_and_sustainability_information/TAKATA). Here, clearly, 
responsibility needed to be reciprocal: if an employee was willing to criticize management neglect, then management should have responded much more positively. Under the reciprocity of CC, this would have been unconditional and not looked upon with suspicion as if Lillie's criticism had come from a whistleblower.

Between 2015 and 2016, Takata's share-value dropped 80 percent and on top of that in November 2015 regulators in the USA fined the company $\$ 70$ million. (http://money.cnn.com/2016/05/06). By June 2017 Takata had negotiated a company sale price of $\$ 1.6$ billion to Key Safety, its Chinese-owned rival, as it filed for bankruptcy protection, causing its shares to be suspended from the Nikkei, (Soble and Merced, June 16, 2017). Therefore it is clear that whilst consumers suffered a physical death, shareholders suffered a financial one. Under an extended definition and practice of corporate citizenship such dislocation would have been less likely to occur. Both management and non-management would have seen the danger of non-intervention with regard to the company's future.

\subsection{Untoward Collaboration: Corporate Citizenship at Its Worst}

Volkswagen intentionally risked their reputation as well. In 2014, the Environmental Protection Agency (EPA) in the USA learned that the company had installed "defeat devices" in a number of different diesel models which could detect the difference between a vehicle being on a test-bed and the road. Software could determine this by means of identifying steering, acceleration and other characteristics which differed from one driving mode to another. The software enabled low emission on a test-bed, but on the road emission of toxic nitrogen dioxide could climb to 40 times the limit set by the USA government. (Atiyeh, http://blog.caranddrivercom/everything p.2). The financial outcome of this deception was that between September of 2015 and September 2016, more than 25 percent of the maker's market capitalization was lost. By October 2016, a settlement was reached with the US courts for $\$ 14.7$ billion with a variety of payouts to purchasers depending on the depreciation of the specific model but private claims also had to be settled. The Department of Justice however, decided that in addition, a $\$ 4.3$ billion fine and six VW arrests would be actioned. (Ibid. p.5).

It is clear that this episode was a case of fraudulent behavior by two companies, Volkswagen and Bosch. VW considered that it could achieve a greater market share, especially in the USA, by marketing diesel powered vehicles to off-set the rise in popularity of electrical vehicles even if those were only just beginning to capture the imagination as a concept by the environmentally-conscious.

Volkswagen itself did not produce the software at the center of the scandal. It was developed by Bosch as far back as 2006. (http://www.nyt.com/2017). As a supplier, Bosch faces court-action at the time of writing. The deception perpetrated by both is significant for several reasons: it was deliberately planned to foil emission controllers; it paid scant attention to the concerns of consumers who had faith in the auto-maker's stated aversion to air-pollutants; and the company focused instead on meeting extravagant aims such as becoming the world's 
largest auto-maker by 2018, apparently with a sub-text that read: 'regardless of how this might be achieved.' (Atiyeh, http://www.blog.caranddriver). To the disillusioned purchasers of the Beetle, Passat, Jetta and Golf all this seemed like industrial collaboration designed to deceive a generation of environmentally-conscious purchasers. As much as anything, it was a betrayal of trust. With the EUGT experimentation in New Mexico, the three German car giants finally appeared to have destroyed their chances of rescuing diesel when a German federal court decision on $27^{\text {th }}$ February 2018 found that city municipalities has the right to ban diesel vehicles wherever urban "hot-spots" caused air pollution. In Figure 1, this is classified under "Manipulation for advantage" in the far left column because it demonstrates unacceptable ethics and risk. As in the case of GM, risk is a double-edged sword that cuts the consumer and the producer down at the same time. This can be compared to Enron. Hatch and Cunliffe note that when Wall Street analysts assessed Enron in 1998, staff were relocated, fake trading rooms were constructed to produce fake trading accounts. (P. 55).

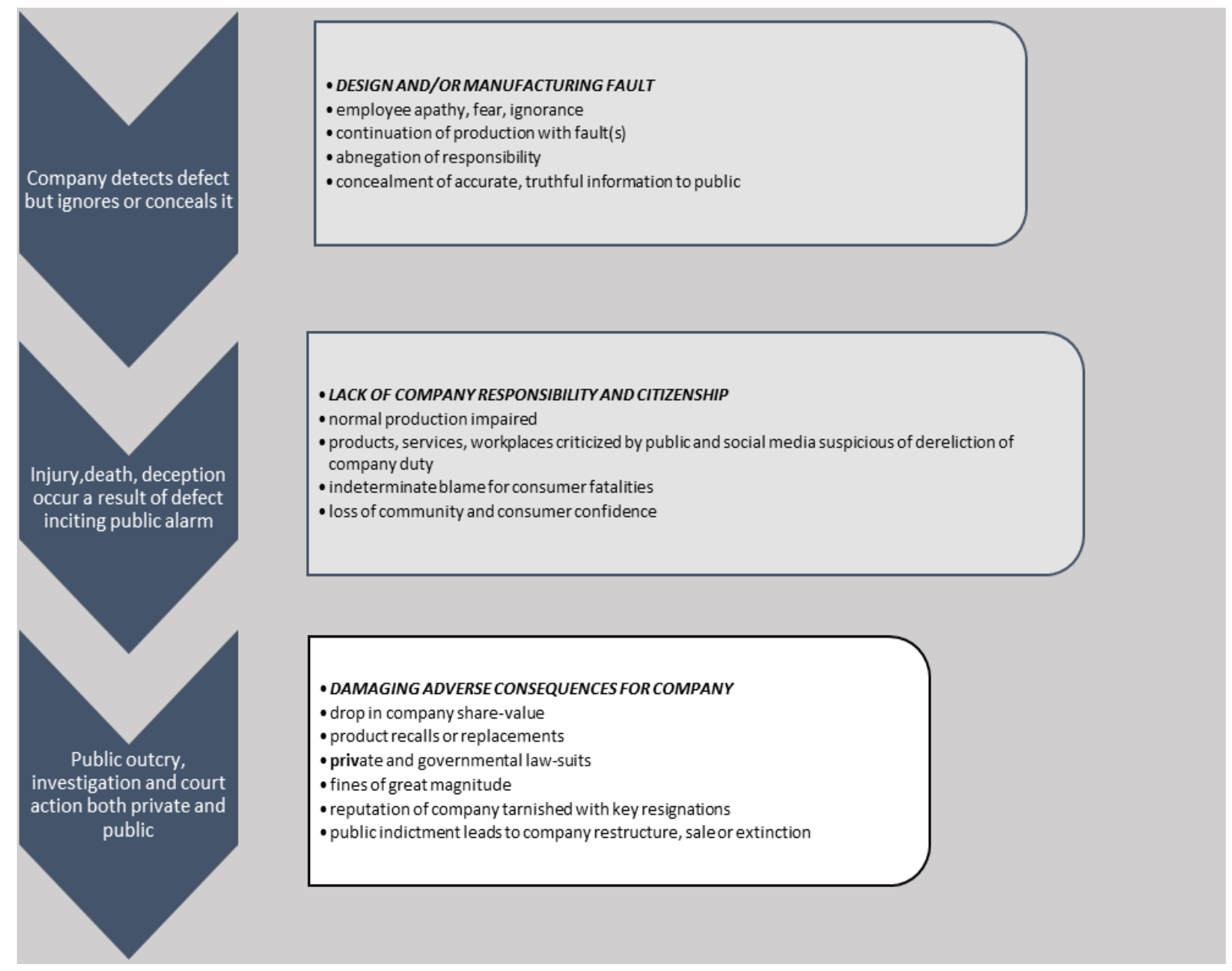

Figure 1. The Downward Trend towards Corporate Self-Defeat

When Figure 1 is related to Figure 2, a new perspective emerges. "Consumer injury” can now also be seen as "producer injury." The downward spiral automatically generated by companies guilty of neglect and irresponsibility ends with them paying for their mistakes. When this continues through a protracted period of time, human fallibility shifts to the left 
column of the "Unacceptable" in Figure 1, and ends with "Public outcry, investigation and court action both private and public" in Figure 2. At that point, human fallibility becomes criminal because CC has disintegrated. This is the very reason that it needs to be more widely recognized as a cornerstone of company integrity.

Improving industrial integrity is not just a matter of process. It is also a matter of paradigm. If industry does not place the highest value on human life it cannot eliminate the problems of its own making. CC must exert sufficient pressure to forestall human fallibility at the extreme ends where criminality and dereliction of responsibility rear their ugly heads. Therefore, it is imperative that the concept of corporate citizenship should be extended to include the roles played by non-management. Non-management is integral to corporate integrity. Management should not interpret this as its responsibility alone and should provide guidance to non-management. That also includes information to non-management.

\section{Analysis and Discussion}

What all of these companies have in common goes beyond the reasonable or accidental. In each case there is a distressing discrepancy between what the company maintains in the themes of its CSR and its actions. It has the effect of back-firing. Returning to the cases in point: General Motors neglected its collective responsibility. The Valukas Report which emanated from the internal investigation of the ignition-switch crisis concluded, "No sense of urgency. No accountability or responsibility. A siloed mentality.” (https://fastcompany.com3064064). Mary Barra used her company’s disaster to attempt a radical change in work-culture. Cultures are difficult to change. If corporations are motivated by the drive towards reducing overheads, the perpetrators who were responsible for allowing the switch problem to go on for so many years must not have been aware that the inevitable dive in share-prices would undermine their best efforts. Stock fell from \$39 to \$32. (Ibid. p.2). In April 2014, Mary Barra stated that, “[Our] new way of developing vehicles will provide the highest levels of safety, quality, and customer service.” (Jusko, 14 November 2015, http://industryweek.com). It is ironic that General Motors' CSR statement still does not include a statement on safety and respect for human life. It does talk about image and revenues. It also talks about its commitments in relation to its stakeholders but not the community at large. In other words, the company focuses on its own "family." But CSR should go beyond the limitations of introspection. The dip in share-value as seen above is repeated in every other company mentioned in this investigation.

Bosch which for years provided VW with its software to commit fraud states the following in its CSR commitment:

Bosch has always been driven by its values. We accept that our actions must accord with the interests of our society. Above all else, we place our products and services in the interests of the safety of people, the economic use of resources, and environmental sustainability. Robert Bosch Engineering and Business Solutions Private Limited through the years has been loyal to the fundamentals that drive the Corporate Social 
Responsibility (CSR) charter. The Social Responsibility charter is aligned to [the] vision towards extending 'Smart Solutions' to create long lasting value to the society. All initiatives are broadly classified into 3 heads: University research; projects in the areas of education and environment; and holistic village development. (in Irfan, 18 December 2014, https://www.nytimes.com/2017/02/01/business/bosch-vw-diesel-settlement.html?mcubz $=3)$.

The disparity between what Bosch says and the way it collaborated with VW in such an untoward way emphasizes the vulnerability of consumers and the duplicity of CSR statements.

Even though GM dismissed 15 employees whom it considered the most responsible for the switch defect, there was never an explanation of how this was determined beyond the company admitting to apathetic bureaucracy and neglect - what Barra refers to as the "old GM” and the "new GM.” It is a nebulous justification for years' lack of responsibility towards the safety interests of their customers. It will never be made clear to what extent the 15 were responsible, and the extent to which management was not responsible. It may be too cynical to speculate that there was a degree of scapegoating, and yet it also appears disingenuous for the company to hide behind accusations of employee guilt when it states publicly that management was not aware of the fault and that there was no conspiracy. That was the finding of the internal inquiry. Yet, that does not comply with the definition of corporate citizenship. Inaction by the management, and a consistent lack of collaboration with non-management, however that may be explained, became a key part of GM's downward trend.

When it became evident that drivers and passengers were losing their lives in GM vehicles, it begs the question as to why there was no investigation and who should have taken responsibility for initiating one. Who knew what and when? Can this re-occur? This also applies to the management of Takata. To whom is management responsible if not its customers and employees, especially in light of CSR claims in which these corporates make a show of concern for the community? On many levels, the moral responsibility lies with middle and senior management under the modern concept but under the post-modern concept that is no longer so valid. In corporate cultures, management designs the strategies, sets the trends, leads by example, and establishes the moral codes - in accordance with values by which they should espouse the "people" element first. That includes non-management to create a new concept of corporate citizenship. That should be elevated to the top priority. When these values are not explicitly stated, employees are prone to overlooking them at best and totally ignoring them at worst. Yet customers take it for granted that corporates have their best interests at heart, and that where there may be a defect or two, a life-threatening condition is not one of them. That causes a gap in the trust between producer and consumer.

In cases above, each has been indicted by the judicial systems in that part of the world to which they are subject. Again, in each case, people became victims first; then companies 
suffered share-value declines; after which brands and reputations were disparaged - but companies survived on public commitments to do better. Large companies like the examples in this investigation demonstrate an almost tacit acquiescence that in the relationship between them and their stakeholders, ambiguity is an aspect of corporate communications. This appears to be on the verge of becoming a 'new normal' in public relations. This forces customers to look to regulatory bodies' reports to discover the history of companies from whom they buy products to see if there are product incongruities. 'Buyer beware' should not cover a potential life-threatening situation especially when corporations have gone to some length to disguise their failings with CSR statements that misrepresent the truth. It should not be given the opportunity to become the new normal. The new concept of CC should become the new normal.

It is clearly difficult for companies to be both the producer who wishes to sell, and their own "police," whose job it is to ensure that defects be immediately intercepted. Yet that antithetical position is possible under a form of CC in which everyone plays a leadership role when necessary. Admittedly, the profit motive is a key part of the commercial condition. That is why the shareholder versus consumer-safety problem is such a difficult one to solve, and is exacerbated through the confusion that surrounds the old concept of corporate citizenship in which specific responsibility is so diffuse and programs only focus outwardly. This is made worse when defects only show up sporadically rather than constantly and are not actioned when detected. But if management, non-management and shareholders recognized that defective conditions inevitably lead to a downward spiral with severely negative consequences for corporates, more would be done to ensure that CC and product safety will be regarded as a greater priority.

\section{Conclusion}

The value of this article lies in its critical analysis of poor ethical operations in the auto-industry and concludes that when ethics are ignored both the consumer as well as the producer suffer the consequences. It is not just a matter of one party being disadvantaged. This doubly endorses the practice of ethics. Ethical practice must outweigh profits and recognize ethical sensitivities in the public conscience. To clarify the issues, CSR and CC have been refined and given distinct definitions; in the literature thus far the two tend to be indistinguishable and that former situation has not assisted the advancement of the theory on ethics. Future discussions on ethics in industry where CSR and CC play a part should benefit from the clarity.

People in their hundreds have suffered needlessly due to ill-defined notions of corporate citizenship which has led to negligence or disregard for human safety during the last decade. These deaths have been proven by courts to not be accidental. Innovative products and services require close scrutiny and any defects must be corrected immediately. Human life should not be the price of remedial action. Some companies identified in this investigation were responsible for years' of indifference towards their customers by focusing their prime concerns towards cost reduction as well as ignoring the fact that corporate citizenship 
necessitates the additional dimension of including responsibility by the non-managerial sector within a company. Whenever a company takes the risk of seeing management or non-management as having sole responsibility instead of mutual responsibility, it can easily lead to corporate self-defeat which means that shareholders lose as well as consumers. In one instance at least, it can be shown that defrauding the public as well as regulators was intentional. That makes their negligence even worse. This is corporate citizenship at its very worst. Ethical production demands a conscious attempt to do "right" by all stakeholders. The article has refined the differences between CSR and CC and the parts they play in corporate ethics.

The problem has two faces. All stakeholders should all be in receipt of corporate yield, not only the specific segments of it which may be able to exert more pressure on management than others. Shareholders are a part of the industrial base, but their interests should never over-ride human life. Employees as the non-managerial component of post-modernist industrial practice as well as consumers therefore should exert as much pressure as shareholders to produce the best possible outcomes for the corporation as well as society as a whole. Ethics dictates fairness towards everyone. Penalties for violations can be severe as can public disapproval which means that corporates should never wittingly or unwittingly fall into traps of their own making; the "unwitting" requires vigilance. If companies become remiss they can do themselves considerable damage in exchange for gains that are dubious at best and criminal at worst. Society should have zero-tolerance for companies that knowingly disregard corporate responsibility, corporate citizenship and the inviolability of human life. Likewise, shareholders should have zero-tolerance for companies that reduce dividends because they are paying heavy fines instead. Human fallibility has many dimensions. Human fallibility can be influenced but imposed controlled have limited efficacy. Defects will always arise but at least every attempt should be made to minimize them and an enhanced, extended view of corporate citizenship is one means to that end because it highlights a broader set of responsibilities in all corporations. That should be recognized and respected in actual practice.

Generally, auto-companies build quality products and services that are fit for purpose. They publish CSR statements which have integrity because these companies see themselves serving their communities and all stakeholders alike and in equal proportion. Their internal corporate citizenship is in alignment as it clearly is in Figure 2. Naturally, in competitive markets they must be profitable. Such a claim cannot be summarily dismissed because undeniably, companies must thrive. However, the auto-companies which were selected in this investigation had records of customer and/or employee negligence which they exhibited through a regrettable disregard for safety and public ethical opinion over lengthy periods. This was then compromised further by false claims on their products, websites, work-places and to government regulators. This should not be a matter of winners and losers. Corporate citizenship mitigates against being a "loser" and the human lives on which their products impinge are beyond price. 
Future directions for research in this field may focus on ethical aspects of other consumer products and services. The auto-industry is not the only ambivalent one.

\section{References}

Ackoff, R. (1978). The Art of Problem Solving. New York: Wiley \& Sons.

Atiyeh, C. (11 May 2017). Retrieved July 19, 2018, from http://www.caranddriver.com/everything-you-need-to-know-about-the-vw-diesel-emissions-s candal/

Baron, D. (2012). Business and its Environment. (7 ${ }^{\text {th }}$ ed.). Pearson Education International. Retrieved from https://onlinelibrary.wiley.com/doi/abs/10.2307/3325105

Brusoni, S., \& Vaccaro, A. (2016). Ethics, Technology and Organizational Innovation. Journal of Business Ethics. https://doi.org/10.1007/s10551-016-3061-6

Bryden, J., \& Gezelius, S. (25 January 2017). Innovation as if people mattered: The ethics of innovation for sustainable 101-118. https://doi.org/10.1080/2157930X.2017.1281208

Caulkin, S. (2003). Retrieved July 12, 2018, from https://www.theguardian.com/business/2003/jan/26theobserver.observerbusiness11

Choudhury, S. (26 June 2017). Retrieved 1 August 2018, from https://www.cnbc.com/2017/06/26/takata-files-for-bankruptcy-in-us-japan-and-likely-sellingassets-to-us-auto-parts-supplier.html

Chui, M. (January 1999). Winners and Losers in a North-South Model of Growth, Innovation and Product Cycles. Journal of Development Economics 65(2291). https://doi.org/10.1016/S0304-3878(01)00140-7

Consumer Reports, (21 October 2016). Retrieved 1 August 2018, from http://www.consumerreports.org/cro/news/2016/05/everything-you-need-to-know-about-the-t akata-air-bag-recall/index.htm accessed 12 July 2018.

Drucker, P. (1984). The Temptation to Do Good. Retrieved 2 November 2018, from https://openlibrary.org/works/OL2721805W/The_temptation_to_do_good

Fabian, C., \& Fabricant, R. (5 August 2014). The Ethics of Innovation. Stanford Social Innovation Review. 28 September 2018, from https://ssir.org/articles/entry/the_ethics_of_innovation

Fox, J., \& Lorsch, J. (July-August 2012). What Good are Shareholders? Harvard Business Review. $\quad$ Retrieved $\quad 3 \quad$ September $\quad 2018$, from https://hbr.org/2012/07/what-good-are-shareholders

France-Presse, A. (16 April 2014). Retrieved 12 August 2018, from http://www.industryweek.com/transportation/gm-chief-creats-new-team-boost-vehicle-safety 
France-Presse, A. (5 June 2015). Retrieved 15 August 2018, from http://www.industryweek.com/companies-executives/gm-takes-responsibility-ignition-scanda l

France-Presse, A. (9 June 2014). Retrieved 22 August 2017, from http://industryweek.com/corporate-responsibility/new-york-court-hear-gm-faulty-ignition-law suits

Freeman, R. E. (1984). Strategic Management: A Stakeholder Approach. Pitman series in Business and Public Policy.

Goldman Sachs. (2016). Business principles and standards. Retrieved 21 September 2018, from http://www.goldmansachs.com/who-we-are/business-standards/business-principles/

Hall, J., \& Rosson, P. (2006). The Impact of Technological Turbulence on Entrepreneurial Behavior, Social Norms and Ethics: Three Internet-based Cases. Journal of Business Ethics. Springer, 64, 231-248. https://doi.org/10.1007/s10551-005-5354-z

Jeff-Smith, H. (Summer 2003). Should companies seek only to maximize shareholder value or strive to serve of often conflicting interests of all stakeholders? MITSloan Management Review, http://sloanreview.mit.edu/article/the-shareholders-vs-stakeholders-debate/ accessed 29 September 2018. Reprint article \#44411.

Jusko, J. (14 November 2014). Retrieved 4 September 2017, from http://www.industryweek.com/quality/ceo-mary-barra-driving-culture-change-general-motors

Kilkullen, M., \& Kooistra, J. (1999). At Least Do No Harm: Sources on the Changing Role of Business Ethics and Corporate Social Responsibility. Reference Services Review, 27(2), 158-178. https://doi.org/10.1108/00907329910275150.

Kogan, L., Papanikolaou, D., \& Stoffman, N. (January 2013). Winners and Losers: Creative Destruction and the Stockmarket. NBER Working Paper No.18671.

Korosec, K. (24 August, 2015), Retrieved 1 September 2018, from http://fortune.com/2015/08/24/feinberg-gm-faulty-ignition-switch/

Kurtzman, D. (30 May 2016). Retrieved 13 September 2017, from http://politicalhumor.about.com/od/stupidquotes/a/gulf-oil-spill-quotes.htm

Mares, R. (Ed.), (2012). The UN Guiding Principles on Business and Human Rights Foundations and Implementation. Martinus Nijhoff Publishers.

Meel, M., \& Saat, M. (2002). Ethical Life Cycle of an Innovation. Journal of Business Ethics, 39, 21-27. https://link.springer.com/article/10.1023/A:1016319714894

Mintzberg, H. (31/03/2017). Retrieved 6 September 2018, from http://www.mintzberg.org/blog/judgment

Mintzberg, M. Simons, R., \& Basu K. (Fall 2002). Beyond Selfishness. MIT Sloan 
Management Review. https://sloanreview.mit.edu/

Mullen, J. (6 May 2016). Retrieved 11 September 2018, from http://money.cnn.com/2016/05/06/news/companies/takata-airbags-recall-shares-crash-what-n ext/

Orlove, R. (2 June 2016). The Complete Story of Takata Airbags and the Biggest Recall in Auto History. Jalopnik. https://jalopni.com/the-complete-story-of-takata-airbags-and-the-biggest-re-1780143

Oxford Dictionary of Business and Management, (2006). (4 ${ }^{\text {th }}$ ed.). OUP.

Porter, M. E., \& Kramer, M. R. (2011). Retrieved 4 August 2018, from https://hbr.org/2011/01/the-big-idea-creating-shared-value

Rothfeder, J. (10 August, 2015). Retrieved 1 September 2018, from http://www.strategy-business.com/blog/The-True-Lesson-of-an-Airbag-Disaster?gko=bcbc1

Scudder, V. (Summer 2014), Retrieved 1 September 2018, from http://apps.prsa.org/Intelligence/TheStrategist/Articles/view/10707/1096/How_a_Culture_of_ Secrecy_Plagued_GM\#.WbEQWrljGUk

Smith, G., \& Parloff, R. (March 15, 2016). Hoaxwagen: How the massive diesel fraud incinerated Vokswage's reputation - and will hobble the company for years to come. Fortune, 173(4), 34-50. http://fortune.com/inside-volkswagen-emissions-scandal/

Stangis, D., \& Valvoda Smith, K. (2017). 21 $1^{\text {st }}$ Century Corporate Citizenship: A Practical Guide to Delivering Value to Society and Your Business.” Emerald Publishing. ISBN 978-1-78635-610-9. $\quad$ Retrieved 5 November 2018, from http://www.emeraldinsight.com.ezproxy.kustar.ac.ae/doi/pdfplus/10.1108/978-1-78635-609-3 20161013

Tetzeli, R. (17 October 2016). Retrieved 25 September 2017, from https://www.fastcompany.com/3064064/most-innovative-com;panies/mary-barra-is-remaking -gms-culture-and-the-company-itself

Trevino, L., \& Nelson, K. (2011). Managing Business Ethics. (5 ${ }^{\text {th }}$ ed.). London: Wiley. https://www.amazon.com/Managing-Business-Katherine-published .../B008BWXD80

Valor, C. (2005). Corporate Social Responsibility and Corporate Citizenship: Towards Corporate Accountability. Business and Society Review. Blackwell Publishing: MA, 110, 2 191-212.

Retrieved

from

https://onlinelibrary.wiley.com/doi/abs/10.1111/j.0045-3609.2005.000aa.x

Zappata, G. (2003). https://www.slideshare.net/nco71/good-corporate-citizenship accessed 22 November 2018. 


\section{Macrothink}

\section{Website}

http://guides.main.library.emory.edu/c.php?g=50422\&p=325039 accessed 2 August 2018.

http://legal-dictionary.thefreedictionary.com/sumer+protection accessed 4 September 2018.

http://www.bbc.com/news/world-europe-42858668 accessed 11 February 2018.

https://fortune.com/2015/08/24/feinberg-gm-faulty-ignition-switch/ accessed 2 August 2018.

https://fortune.com/2015/09/18/mary-barra-gm-culture accessed 2 August 2017.

https://www.ftc.gov/about-ftc/bureaus-offices/bureau-consumer-protection accessed 1 October 2018.

https://www.google.ae/search?q=chart+of+share+drop+BP+2010-215\&tbm=isch\&source=iu \&pf=m\&ictx=1\&fir=V6vR1RDs5v1xbM\%253A\%252COv-UgIBf5XHKUM\%252C_\&usg= __azgJNs03p4iiIRSfzZlh42OASMA\%3D\&sa=X\&ved=0ahUKEwj29uKlkdnWAhUMahoKH QppCwcQ9QEINzAC\#imgrc=V6vR1RDs5v1xbM: accessed 1 October 2018.

https://www.google.ae/search?q=cladding+on+the+address+building+that+caught+fire $+\mathrm{in}+\mathrm{d}$ ubai\&oq=cl\&aqs=chrome.0.35i39j0j69i57j69i61j0l2.4614j0j8\&sourceid=chrome\&ie=UTF-8 accessed 10 October 2018.

https://www.nytimes.com/2017/02/01/business/bosch-vw-diesel-settlement.html?mcubz=3 accessed 2 October 2018.

https://www.nytimes.com/2018/01/28/business/german-carmakers-diesel-monkeys.html accessed 21 February 2018.

https://www.theguardian.com/business/2003/jan/26/theobserver.observerbusiness11 accessed 2 October 2018.

\section{Copyright}

Copyright for this article is retained by the author(s), with first publication rights granted to the journal.

This is an open-access article distributed under the terms and conditions of the Creative Commons Attribution license (http://creativecommons.org/licenses/by/4.0/). 